\title{
High sensitivity of $\beta$-cell replication to the inhibitory effects of interleukin-1 $\beta$ : modulation by adenoviral overexpression of IGF2 in rat islets
}

\author{
Elisabet Estil.les ${ }^{1}$, Noèlia Téllez ${ }^{1,2}$, Joan Soler ${ }^{1,2,3}$ and Eduard Montanya ${ }^{1,2,3}$ \\ ${ }^{1}$ Laboratory of Diabetes and Experimental Endocrinology, Department of Clinical Sciences, IDIBELL-University of Barcelona, Feixa Llarga s/n 08907 L'Hospitalet \\ de Llobregat, Barcelona, Spain \\ ${ }^{2}$ CIBER de Diabetes y Enfermedades Metabólicas Asociadas (CIBERDEM), 08036 Barcelona, Spain \\ ${ }^{3}$ Endocrine Unit (13-2), IDIBELL-Hospital Universitari Bellvitge, Feixa Llarga, s/n 08907 L'Hospitalet de Llobregat, Barcelona, Spain \\ (Correspondence should be addressed to E Montanya at Endocrine Unit (13-2), IDIBELL-Hospital Universitari Bellvitge; Email: montanya@ub.edu)
}

\begin{abstract}
Interleukin-1 $\beta$ (IL1B) is an important contributor to the autoimmune destruction of $\beta$-cells in type 1 diabetes, and it has been recently related to the development of type 2 diabetes. IGF2 stimulates $\beta$-cell proliferation and survival. We have determined the effect of IL1B on $\beta$-cell replication, and the potential modulation by IGF2 and glucose. Controluninfected and adenovirus encoding for IGF2 (Ad-IGF2)infected rat islets were cultured at 5.5 or $22.2 \mathrm{mmol} / 1$ glucose with or without $1,10,30$, and $50 \mathrm{U} / \mathrm{ml}$ of IL1B. $\beta$-Cell replication was markedly reduced by $10 \mathrm{U} / \mathrm{ml}$ of IL1B and was almost nullified with 30 or $50 \mathrm{U} / \mathrm{ml}$ of IL1B. Higher concentrations of IL1B were required to increase $\beta$-cell apoptosis. Although IGF2 overexpression had a strong mitogenic effect on $\beta$-cells, IGF2 could preserve $\beta$-cell proliferation only in islets cultured with $10 \mathrm{U} / \mathrm{ml} \mathrm{IL1B}$, and
\end{abstract}

had no effect with 30 and $50 \mathrm{U} / \mathrm{ml}$ of IL1B. In contrast, IGF2 overexpression induced a clear protection against IL1B-induced apoptosis, and higher concentrations of the cytokine were needed to increase $\beta$-cell apoptosis in Ad-IGF2-infected islets. These results indicate that $\beta$-cell replication is highly sensitive to the deleterious effects of the IL1B as shown by the inhibition of replication by relatively low IL1B concentrations, and the almost complete suppression of $\beta$-cell replication with high IL1B concentrations. Likewise, the inhibitory effects of IL- $\beta$ on $\beta$-cell replication were not modified by glucose, and were only modestly prevented by IGF2 overexpression, in contrast with the higher protection against IL1B-induced apoptosis afforded by glucose and by IGF2 overexpression.

Journal of Endocrinology (2009) 203, 55-63

\section{Introduction}

$\beta$-Cell mass reduction has a central role in the development of type 1 and type 2 diabetes, and in both conditions the loss of $\beta$-cells has been largely attributed to increased $\beta$-cell death (Butler et al. 2003, Devendra et al. 2004). Recent reports have highlighted the fundamental contribution of $\beta$-cell replication to the physiological maintenance of $\beta$-cell mass (Montanya et al. 2000, Meier et al. 2008), and to $\beta$-cell mass regeneration in models with reduced $\beta$-cell mass (Dor et al. 2004, Nir et al. 2007). This may suggest that impaired $\beta$-cell replication could contribute to the reduction of $\beta$-cell mass in diabetes.

Interleukin-1 $\beta$ (IL1B) is an important contributor to $\beta$-cell damage in type 1 diabetes (Mandrup-Poulsen 1996), and recently it has also been related to the development of type 2 diabetes (Larsen et al. 2007). It is well established that IL1B, alone or in combination with other pro-inflammatory cytokines interferon- $\gamma$ (IFNG) and tumour necrosis factor- $\alpha$ (TNF), induces $\beta$-cell death in mouse, rat, and human islets
(Saldeen 2000, Eizirik \& Mandrup-Poulsen 2001, Mathis et al. 2001). IL1B exerts also an inhibitory effect on $\beta$-cell replication (Eizirik et al. 1990, Southern et al. 1990, Sjöholm 1991, Maedler et al. 2001, Téllez et al. 2005), that has received less attention and is less well defined. In an islet transplantation model, we recently reported that islet overexpression of the IL-1 naturally occurring antagonist, IL-1 receptor antagonist protein, increased $\beta$-cell replication and mass (Téllez et al. 2007), suggesting that IL1B inhibition of $\beta$-replication was relevant in $\beta$-cell mass reduction. Thus, IL1B could play a dual role in $\beta$-cell mass reduction inducing $\beta$-cell death and inhibiting $\beta$-cell replication.

Insulin-like growth factors I and II (IGF1 and IGF2) are potent $\beta$-cell growth factors (Vasavada et al. 2006). In vitro, IGF1 and IGF2 promote DNA synthesis in $\beta$-cell lines, and in rat and human fetal $\beta$-cells (Hogg et al. 1993, Asfari et al. 1995, Huotari et al. 1998). In vivo, the mitogenic effect of IGF2 was shown in transgenic mice overexpressing Igf2 gene (Petrik et al. 1999a). IGF1 and -2 can also increase $\beta$-cell survival. In early neonatal life there is a wave of apoptotic 
$\beta$-cell death (Scaglia et al. 1997) that has been linked to the concomitant reduction in IGF2 expression (Petrik et al. 1998, Hill et al. 2000). In adult islets, IGF2 survival action has been shown in rats fed with a low protein diet (Petrik et al. 1999b), and in transplanted islets (Robitaille et al. 2003). Thus, IGF2 may play a dual beneficial role on $\beta$-cell mass, acting both as a mitogenic and as a survival factor for $\beta$-cells. Cytokines inhibit the expression of IGFs in several cell types (Ilvemarski et al. 1993, Martin et al. 1993, Lin et al. 1994), and a reduction in IGF2 immunoreactivity has been found in islet cells undergoing insulitis, suggesting that cytokines may inhibit the expression of IGF2 in islet cells (Hill et al. 1999). Although IGF2 may protect islet cells from cytokine-induced apoptosis (Hill et al. 1999), some studies have shown no effect of IGFs on IL1B-induced apoptosis (Raile et al. 2003), and it is not known whether IGF2 could modify IL1B-induced suppression of $\beta$-cell replication. In this study we aimed to investigate the effect of IL1B on $\beta$-cell replication, and the potential modulation by IGF2. Since the induction of $\beta$-cell proliferation by IGFs is dependent on ambient glucose concentration (Hügl et al. 1998), low and high glucose concentrations were used to better define the effects of IL1B and IGF2 on $\beta$-cell replication.

\section{Material and Methods}

\section{Islet isolation}

Islets from male LEW/SsNHsd rats (Harlan, Horst, The Netherlands; 6-8 weeks old, 175-200 g of body weight) were isolated by collagenase (Collagenase P; Roche Diagnostics) digestion of the entire pancreas as previously described (Nácher et al. 1996). Isolated islets were hand-picked under a stereomicroscope two or three times, until a population of pure islets was obtained. Islets were washed in serum-free RPMI 1640 11.1 mmol/l glucose (Sigma Immunochemicals) supplemented with $100 \mathrm{U} / \mathrm{ml}$ penicillin and $100 \mu \mathrm{g} / \mathrm{ml}$ streptomycin before infection. Each experiment was performed using a pool of 1000-1200 islets obtained from four rats in a single isolation procedure. The islets of the pool were then randomly distributed among the different experimental conditions studied in each experiment. Each condition was studied in 3-11 different experiments, as indicated in figure legends.

\section{Recombinant adenoviruses}

E1-E3-deleted adenoviral vectors were used for islet transfection. Adenovirus encoding for green fluorescent protein (Ad-GFP) was used to assess the efficiency of infection, and adenovirus encoding for luciferase (Ad-Luc) as control of infection. Ad-GFP, Ad-Luc, and adenovirus encoding for IGF2 (Ad-IGF2) were generated by Pacific Northwest Research Institute (Seattle, USA). In all adenoviral vectors the transgene was driven by the cytomegalovirus (CMV) promoter.

\section{Gene transfer}

Groups of 200 islets were left uninfected (uninfected control group), or infected with Ad-Luc, Ad-GFP, or Ad-IGF2 at a plaque-forming unit of $7 \times 10^{7}$ in $400 \mu \mathrm{l}$ serum-free RPMI $164011 \cdot 1 \mathrm{mmol} / 1$ glucose for $2 \mathrm{~h}$ at $37^{\circ} \mathrm{C}$ and $5 \% \mathrm{CO}_{2}$. After infection, islets were washed three times in RPMI 1640 containing 10\% heat-inactivated FCS, and incubated overnight in non-tissue culture-treated plasticware at $37^{\circ} \mathrm{C}$ in serum containing medium at $11.1 \mathrm{mmol} / 1$ of $\mathrm{D}$-glucose.

\section{Islet culture}

After overnight incubation, islets were cultured in RPMI $164010 \%$ FCS, $11 \cdot 1 \mathrm{mmol} / 1$ glucose for $48 \mathrm{~h}$ to determine the efficiency of infection, islet viability, and islet function. To determine the effects of IL1B on $\beta$-cell apoptosis and replication, and the modulation by IGF2 overexpression and glucose, control-uninfected islets and Ad-IGF2-infected islets were cultured for $48 \mathrm{~h}$ in RPMI $164010 \%$ FCS at 5.5 and $22.2 \mathrm{mmol} / \mathrm{l} \mathrm{D}$-glucose with or without $1,10,30$, and $50 \mathrm{U} / \mathrm{ml}$ recombinant human IL1B (BD Pharmingen, Heidelberg, Germany).

\section{Efficiency of infection}

The efficiency of infection was determined by flow cytometry, confocal microscopy, and immunohystochemical confirmation of IGF2 overexpression $48 \mathrm{~h}$ after adenoviral infection.

Flow cytometry Forty-eight hours after infection, Ad-GFP-infected islets were dispersed into single cells and analyzed on a FACS calibur cytometer (Beckton Dickinson Instruments, Heidelberg, Germany) using $488 \mathrm{~nm}$ excitation and a $530 \pm 15 \mathrm{~nm}$ band-pass filter, as previously described (Téllez et al. 2005).

Confocal microscopy In vivo observation of whole Ad-GFP-infected islets with a confocal microscope (Leica TC6-SL Spectral confocal; Mannheim, Germany) was used to determine the distribution of infected islet cells.

IGF2 expression Cultured islets were fixed overnight in 4\% paraformaldehyde at $4{ }^{\circ} \mathrm{C}$, embedded in paraffin, sectioned and immunostained after deparaffinization and rehydratation. Sections were incubated overnight at $4{ }^{\circ} \mathrm{C}$ with a rabbit antihuman IGF2 antibody (final dilution 1:100; Novozymes GroPep, Adelaide, Australia). Visualization was performed with LSAB + System-HRP (DakoCytomation, Carpinteria, CA, USA).

\section{Islet cell viability}

To assess islet cell viability after adenovirus infection, fluorescein diacetate (FDA; Sigma) assay was used (Persidsky \& Baillie 1977). After $48 \mathrm{~h}$ culture, Ad-Luc-infected islets 
were dispersed into single cells, incubated with FDA $(4 \mu \mathrm{g} / \mu \mathrm{l})$ at $37^{\circ} \mathrm{C}, 5 \% \mathrm{CO}_{2}$ for $10 \mathrm{~min}$, and analyzed on the flow cytometer at $488 \mathrm{~nm}$ excitation and a $530 \pm 15 \mathrm{~nm}$ band-pass filter for FDA detection (green).

Propidium iodide (PI) was used to determine islet cell late apoptosis and necrosis. After $48 \mathrm{~h}$ culture, Ad-GFP-infected islets were dispersed into single cells and immediately before cytometric analysis, $0 \cdot 05 \mu \mathrm{g} / \mathrm{ml}$ PI (Sigma) was added. PI fluorescence emission was collected at $620 \mathrm{~nm}$ (red).

\section{Insulin secretion}

Glucose-stimulated insulin secretion was used as a functional assay to determine the effects of adenoviral infection. Control-uninfected islets and Ad-Luc-infected islets were cultured for $48 \mathrm{~h}$ with RPMI 1640 medium supplemented with $11.1 \mathrm{mmol} / 1$ glucose and $10 \%$ FCS. Control-uninfected islets and Ad-IGF2-infected islets were also cultured for $48 \mathrm{~h}$ in RPMI 1640 10\% FCS at 11.1 mmol/1 D-glucose with or without $50 \mathrm{U} / \mathrm{ml}$ recombinant human IL1B to determine the effects of IL1B and IGF2 overexpression on $\beta$-cell function. Cultured islets were then washed twice with Krebs-Ringer bicarbonate buffer supplemented with HEPES and BSA (KRBH buffer: $115 \mathrm{mmol} / \mathrm{l} \mathrm{NaCl} ; 24 \mathrm{mmol} / \mathrm{l} \mathrm{NaHCO}_{3}$; $5 \mathrm{mmol} / 1 \mathrm{KCl} ; 1 \mathrm{mmol} / 1 \mathrm{MgCl}_{2} ; 2.5 \mathrm{mmol} / 1 \mathrm{CaCl}_{2}$; $10 \mathrm{mmol} / 1$ HEPES; and $0 \cdot 5 \%$ BSA, pH 7.4) with $2.8 \mathrm{mmol} / 1$ glucose, and were pre-incubated $1 \mathrm{~h}$ at $37^{\circ} \mathrm{C}$ in triplicate groups of 10 islets in $1 \mathrm{ml}$ fresh $\mathrm{KRBH}$ buffer containing $2.8 \mathrm{mmol} / 1$ glucose. The medium was removed and islets were incubated with $1 \mathrm{ml}$ of $\mathrm{KRBH}$ buffer containing 2.8 or $16.7 \mathrm{mmol} / 1$ glucose for an additional hour with continuous shaking. Supernatants were removed and stored at $-80{ }^{\circ} \mathrm{C}$ until assayed for insulin content. Insulin was measured by ELISA (Mercodia Rat insulin ELISA, Mercodia AB, Uppsala, Sweden).

\section{DNA content}

After the insulin secretion assay, islets were rinsed three times with phosphate buffer $\left(2 \mathrm{M} \mathrm{NaCl} ; 40 \mathrm{mmol} / 1 \mathrm{Na}_{2} \mathrm{HPO}_{4}{ }^{-}\right.$ $\mathrm{H}_{2} \mathrm{O} ; 2 \mathrm{mmol} / 1$ EDTA) to avoid the interfering effect of BSA in the DNA test and were disrupted by sonication. DNA was determined by a fluorimetric assay using Hoechst 33258 (Sigma; excitation wave length $356 \mathrm{~nm}$, and emission wave length $448 \mathrm{~nm}$ ) on a fluorescence spectrophotometer (F-2000, Hitachi Ltd, Tokyo, Japan).

\section{Immunocytochemical quantification of $\beta$-cell apoptosis and replication}

Cultured islets were fixed overnight in 4\% paraformaldehyde at $4{ }^{\circ} \mathrm{C}$, embedded in paraffin, sectioned and immunostained after deparaffinization and rehydratation.

$\boldsymbol{\beta}$-Cell apoptosis Sections were double stained by immunoperoxidase for apoptotic nuclei with the terminal deoxynucleotidyl transferase biotin-dUTP nick end labeling
(TUNEL) technique (In Situ Cell Death Detection Kit, Apop Tag, Intergene, Oxford, UK) and by alkaline phosphatase for the endocrine non- $\beta$-cells of the islets. A cocktail of antibodies (Dako) rabbit anti-swine glucagon (final dilution $1: 1000$ ), rabbit anti-human somatostatin (final dilution $1: 1000$ ), and rabbit anti-human pancreatic polypeptide (final dilution 1:500) were used as previously described (Biarnés et al. 2002). After immunoperoxidase staining, $\beta$-cells and TUNEL positive $\beta$-cells were counted using an Olympus BX microscope connected to a digital camera Olympus DP70 with a color monitor (Téllez et al. 2005). When assessing apoptotic nuclei we excluded necrotic regions. $\beta$-Cell apoptosis was expressed as percentage of TUNEL-positive $\beta$-cells. A minimum of 1200 cells per sample were counted; the sections were systematically sampled, all endocrine nuclei were counted, and when needed a second section was included.

$\boldsymbol{\beta}$-Cell replication The thymidine analog 5-bromo2 'deoxyuridine (BrdU, Amersham) was added to the islet culture for the last $24 \mathrm{~h}$ of culture prior to fixation. Sections were double stained with immunoperoxidase for BrdU using a Cell Proliferation Kit (Amersham) with a modified protocol (Biarnés et al. 2002), and for endocrine non- $\beta$-cells of the islets using the cocktail of antibodies described above. After immunoperoxidase staining, $\beta$-cells and BrdU-positive $\beta$-cells were counted as described for $\beta$-cell apoptosis. $\beta$-Cell replication was expressed as percentage of BrdUpositive $\beta$-cells, and at least 1200 cells were counted.

\section{Nitrite determination}

Nitric oxide (NO) production by islets was measured as nitrite accumulation in culture media (nitrite is a stable product of NO oxidation). Groups of 100 control-uninfected and Ad-IGF2-infected islets were cultured for $48 \mathrm{~h}$ in RPMI 1640 medium without phenol red supplemented with $11.1 \mathrm{mmol} / 1$ glucose and $5 \%$ FCS with or without $10 \mathrm{U} / \mathrm{ml}$ of recombinant human IL1B. Samples of the conditioned media were collected and nitrite was measured by nitrate/nitrite fluorometric assay kit (Cayman Chemical, Ann Arbor, MI, USA).

\section{Statistical analysis}

Results were expressed as means \pm s.E.M. Statistics were performed using SPSS 12.0 (Chicago, IL, USA) for windows, and differences among means were evaluated by the KruskalWallis test, followed by the Mann-Whitney test. A $P$ value of $<0 \cdot 05$ was considered significant.

\section{Results}

\section{Efficiency of infection}

Forty-eight hours after gene transfer $100 \%$ of Ad-GFPinfected islets expressed GFP when observed by confocal microscopy (Fig. 1A). The majority of infected cells were in 

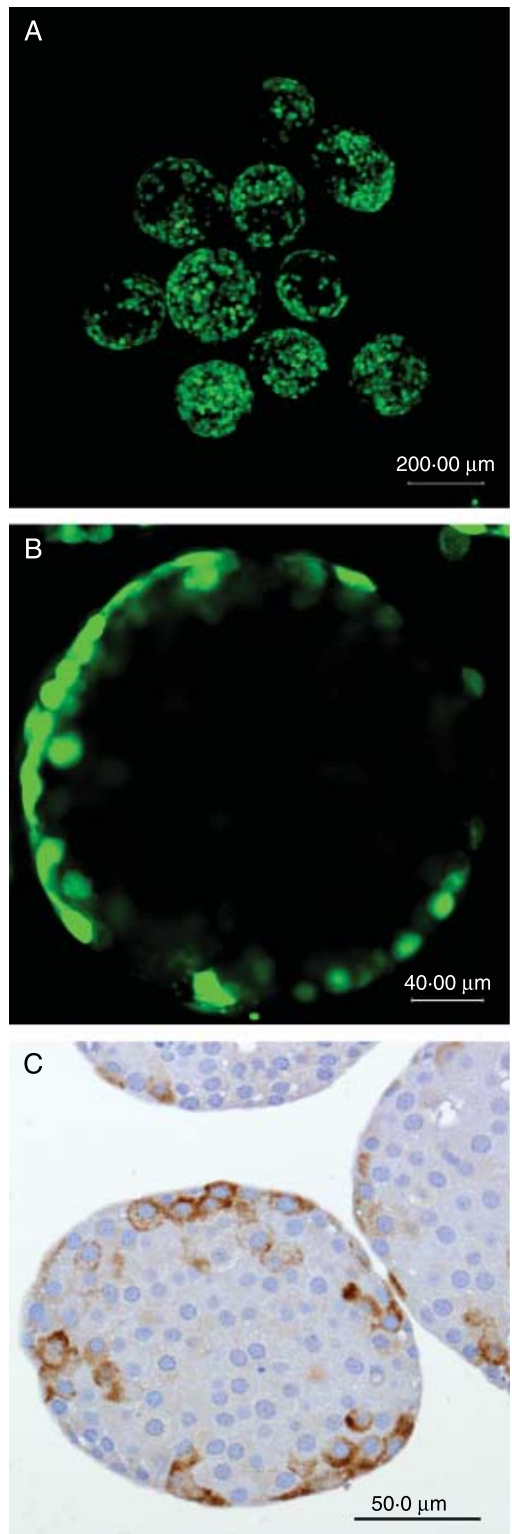

Figure 1 Efficiency of adenovirus islet infection analyzed by confocal microscopy and immunocytochemistry $48 \mathrm{~h}$ after infection. Ad-GFP-infected islets visualized by confocal microscopy showing GFP positive cells (green). The image is a 2D average projection of a series along fixed axis (A). Infected cells were predominantly found in the periphery of the islets, as visualized by confocal microscopy in Ad-GFP-infected islets (green) (B), and in Ad-IGF2-infected islets stained with an anti-IGF2 antibody (brown) (C).

the periphery of the islets (Fig. 1B). The predominantly peripheral expression of IGF2 protein by Ad-IGF2-infected islets was confirmed by immunocytochemical staining with an anti-IGF2 antibody (Fig. 1C). When the efficiency of infection was determined at the level of individual islet cells by flow cytometry of dispersed islet cells, it was found that $29 \%$ of islet cells were infected (Fig. 2).
Adenoviral infection did not modify islet viability and function

Islet viability was similar in control-uninfected and in Ad-Luc-infected islets. In both cases, FDA staining showed 90-95\% viability after $48 \mathrm{~h}$ in culture (data not shown). PI staining yielded similar results, and only $5 \cdot 61 \pm 0 \cdot 54 \%$ of control-uninfected and $5 \cdot 57 \pm 0 \cdot 18 \%$ of Ad-GFP-infected islets cells were found to be stained by PI (Fig. 2). Glucosestimulated insulin secretion was also similar in Ad-Lucinfected and control-uninfected islets (Supplementary Fig. 1, available in the online version of the Journal of Endocrinology at http://joe.endocrinology-journals.org/cgi/content/full/JOE-09-0047/DC1), indicating that adenoviral infection had no effect on $\beta$-cell function.

\section{Effects of IGF2 overexpression on IL1B-induced inhibition of $\beta$-cell-function}

The well-established inhibitory effects of IL1B on $\beta$-cell function were confirmed in control-uninfected islets incubated with IL1B that showed a profoundly impaired glucose stimulated insulin secretion. IGF2 overexpression partly preserved $\beta$-cell function in islets exposed to $50 \mathrm{U} / \mathrm{ml}$ of IL1B that showed an increased insulin secretion in response to $16.7 \mathrm{mmol} / 1$ glucose of borderline statistical significance $(P=0 \cdot 077)$, and an insulin stimulation index that doubled that of control-uninfected islets $(2 \cdot 24 \pm 1 \cdot 69$ vs $5 \cdot 45 \pm 0 \cdot 92$; Supplementary Fig. 2, available in the online version of the Journal of Endocrinology at http://joe.endocrinologyjournals.org/cgi/content/full/JOE-09-0047/DC1).

\section{Effects of IGF2 overexpression on IL1B-induced $\beta$-cell apoptosis}

IL1B increased $\beta$-cell apoptosis in a dose-dependent manner in islets cultured at low $(5.5 \mathrm{mmol} / \mathrm{l})$ and at high $(22.2 \mathrm{mmol} / \mathrm{l})$ glucose concentration (Fig. 3). $\beta$-Cell apoptosis was higher in
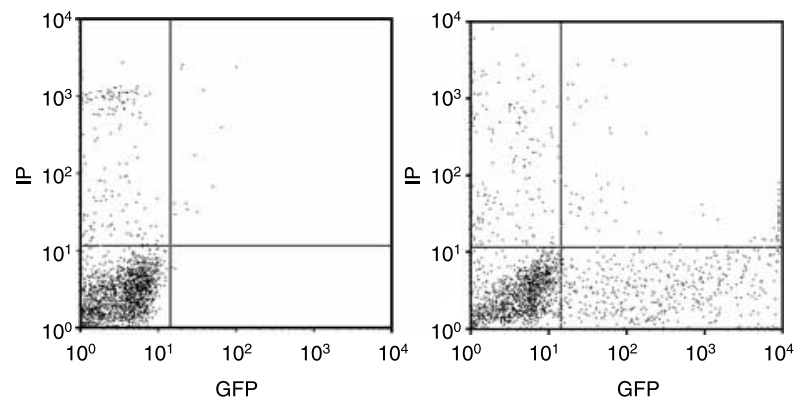

Figure 2 Efficiency of adenovirus islet infection and islet cell viability analyzed by flow cytometry $48 \mathrm{~h}$ after infection. Dispersed islet cells of control-uninfected islets (left dot-plot) and Ad-GFPinfected islets (right dot-plot) were analyzed by flow cytometry for GFP production and propidium iodide (PI) staining. 29\% of individual cells from Ad-GFP-infected islets showed GFP expression, and only $5 \cdot 6 \%$ of both control-uninfected and Ad-GFP-infected islets were stained by PI.

www.endocrinology-journals.org 

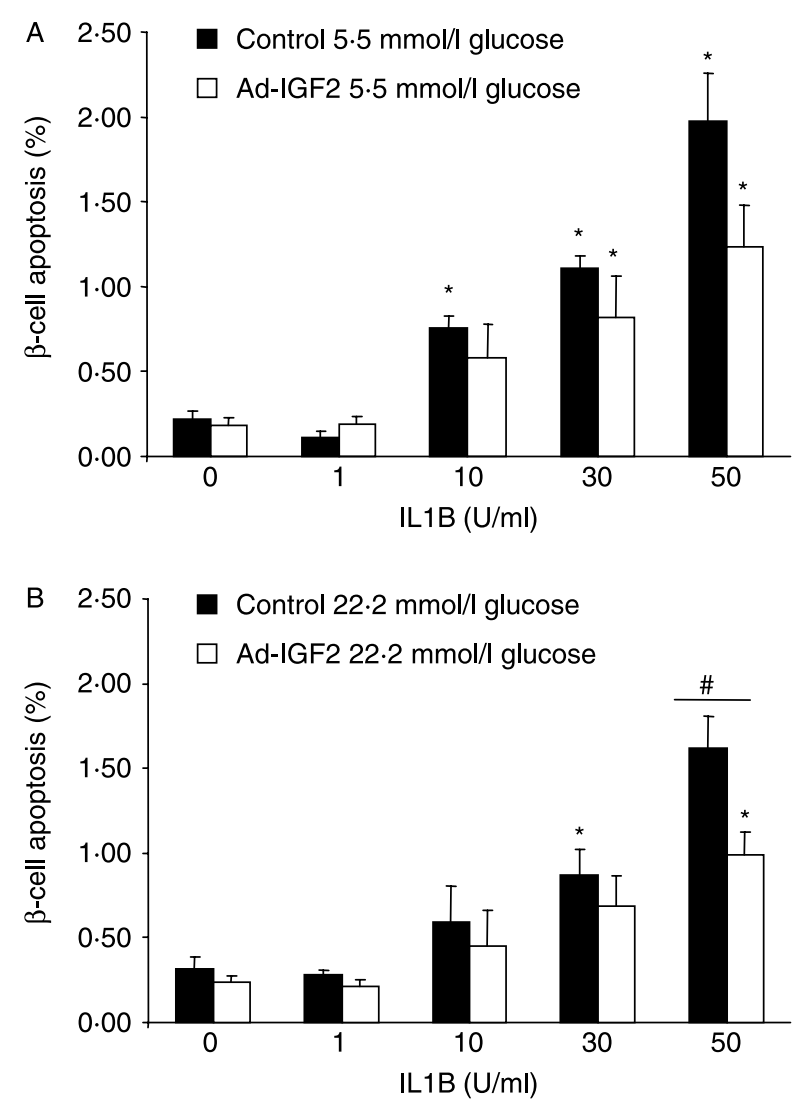

Figure 3 Effect of IL1B and IGF2 overexpression on $\beta$-cell apoptosis. Control-uninfected and Ad-IGF2-infected islets were exposed to $0,1,10,30$ and $50 \mathrm{U} / \mathrm{ml}$ of IL1B, at $5 \cdot 5$ (A) or $22 \cdot 2$ (B) $\mathrm{mmol} / / \mathrm{l}$ glucose for $48 \mathrm{~h}$ to study the effect of IL1B and of IGF2 overexpression on $\beta$-cell apoptosis. Values are means \pm s.E.M. ( $n=9-11$ for control-uninfected and Ad-IGF2-infected islets not exposed to IL1B, and $n=5$ for all other groups). Kruskal-Wallis, $P<0.001$ among all groups cultured at $5.5 \mathrm{mmol} / \mathrm{l}$ glucose (A), or among all groups cultured at $22 \cdot 2 \mathrm{mmol} / \mathrm{l}$ glucose (B). MannWhitney ${ }^{*} P<0.01$ versus control-uninfected group not exposed to IL1B; ${ }^{\#} P<0 \cdot 05$ between control-uninfected islets and IGF2-infected islets cultured with $50 \mathrm{U} / \mathrm{ml}$ IL1B.

islets cultured at low glucose concentration that showed increased apoptosis when exposed to $10 \mathrm{U} / \mathrm{ml}$ or higher concentrations of IL1B. In islets cultured at $22 \cdot 2 \mathrm{mmol} / \mathrm{l}$ glucose, higher concentrations of IL1B (30 and $50 \mathrm{U} / \mathrm{ml}$ ) were required to increase $\beta$-cell apoptosis that was not modified by $10 \mathrm{U} / \mathrm{ml}$ of IL1B.

IGF2 overexpression protected $\beta$-cells against IL1Binduced apoptosis. In islets cultured at $22.2 \mathrm{mmol} / 1$ glucose and exposed to $50 \mathrm{U} / \mathrm{ml}$ of IL1B, $\beta$-cell apoptosis was lower in Ad-IGF2 islets than in control-uninfected islets $(1.62 \pm 0.19$ vs $0.99 \pm 0.13 \%, P<0.03)$. Moreover, a higher concentration of IL1B was required to increase $\beta$-cell apoptosis in Ad-IGF2-infected islets compared to controluninfected islets, both in islets incubated at low (Fig. 3A) and at high glucose (Fig. 3B). In islets cultured at $5.5 \mathrm{mmol} / 1$ glucose, $10 \mathrm{U} / \mathrm{ml}$ of IL1B were sufficient to increase $\beta$-cell apoptosis in control islets but not in Ad-IGF2 islets that had to be exposed to $30 \mathrm{U} / \mathrm{ml}$ IL1B. Similarly, in islets cultured at $22.2 \mathrm{mmol} / 1$ glucose, incubation with $30 \mathrm{U} / \mathrm{ml}$ IL1B increased $\beta$-cell apoptosis in uninfected islets but not in Ad-IGF2 islets that had to be exposed to $50 \mathrm{U} / \mathrm{ml}$ IL1B. Thus, the IL1B pro-apoptotic effect on $\beta$-cells was higher at low glucose concentrations, and was reduced in islets overexpressing IGF2.

Effects of IGF2 overexpression IL1B-induced inhibition of $\beta$-cell replication

IL1B reduced $\beta$-cell replication in islets exposed to 10,30 , and $50 \mathrm{U} / \mathrm{ml}$, both at low and high glucose concentrations (Fig. 4). $\beta$-Cell replication showed a high sensitivity to IL1B as indicated by the dramatic reduction in islets exposed to $10 \mathrm{U} / \mathrm{ml} \mathrm{IL1B}$ and the almost complete suppression with 30 and $50 \mathrm{U} / \mathrm{ml}$ of IL1B.

At $5.5 \mathrm{mmol} / 1$ glucose, $1 \mathrm{U} / \mathrm{ml}$ IL1B increased $\beta$-cell replication compared with uninfected islets not exposed to IL1B. No effect of $1 \mathrm{U} / \mathrm{ml}$ IL1B was detected in islets cultured at $22 \mathrm{mmol} / 1$ glucose. Glucose increased $\beta$-cell replication in uninfected and in Ad-IGF2 islets in the absence of IL1B and in islets exposed to low (1 and $10 \mathrm{U} / \mathrm{ml}$ ) IL1B concentrations.

IGF2 overexpression doubled $\beta$-cell replication in islets cultured at 5.5 and at $22.2 \mathrm{mmol} / 1$ glucose compared with control-uninfected islets, and showed a protective effect on $\beta$-cell replication in islets exposed to $10 \mathrm{U} / \mathrm{ml}$ IL1B that maintained $\beta$-cell replication similar to that of controluninfected islets not exposed to IL1B. At higher IL1B concentrations (30 and $50 \mathrm{U} / \mathrm{ml}$ ), IGF2 overexpression had minimal impact on $\beta$-cell replication that remained almost completely suppressed both in islets cultured at 5.5 and $22 \cdot 2 \mathrm{mmol} / \mathrm{l}$ glucose.

\section{Nitrite production}

Nitrite production was measured to determine whether IGF2 overexpression modified IL1B-induced production of NO. Nitrite accumulation in cell culture supernatants was increased in control-uninfected islets exposed to $10 \mathrm{U} / \mathrm{ml}$ of IL1B for $48 \mathrm{~h}$ (Fig. 5). In contrast, no changes in nitrite accumulation were detected when islets overexpressing IGF2 were exposed to IL1B, indicating that IGF2 prevented the formation of NO in islets exposed to IL1B.

\section{Discussion}

In this study, we show that IL1B has a profound inhibitory effect on $\beta$-cell replication that was partly prevented by adenoviral overexpression of IGF2 on islet cells. The high sensitivity of $\beta$-cell replication to IL1B was established based on the almost completely suppression of $\beta$-cell replication, the absence of modulation by glucose, and the relatively 

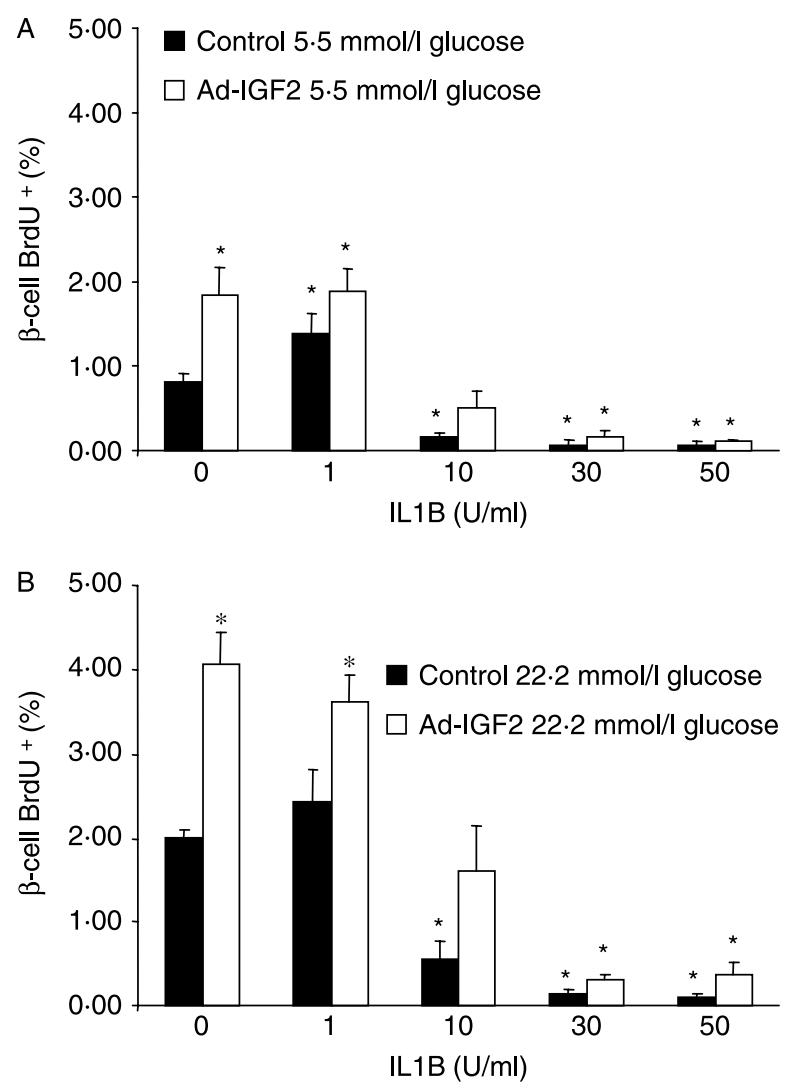

Figure 4 Effect of IL1B and IGF2 overexpression on $\beta$-cell replication. Control-uninfected and Ad-IGF2-infected islets were exposed to $0,1,10,30$, and $50 \mathrm{U} / \mathrm{ml}$ of IL1B, at $5 \cdot 5$ (A) or $22 \cdot 2$ (B) $\mathrm{mmol} / \mathrm{l}$ glucose for $48 \mathrm{~h}$ to study the effect of IL1B and of IGF2 overexpression on $\beta$-cell and replication. Values are means \pm s.E.M. ( $n=9-11$ for control-uninfected and IGF2-infected islets not exposed to IL1B, and $n=5$ for all other groups). Kruskal-Wallis, $P<0.001$ among all groups cultured at $5.5 \mathrm{mmol} / \mathrm{l}$ glucose $(\mathrm{A})$ or among all groups cultured at $22 \cdot 2 \mathrm{mmol} / \mathrm{l}$ glucose (B). MannWhitney, $* P<0 \cdot 05$ versus control-uninfected group not exposed to IL1B.

modest prevention achieved by IGF2 overexpression compared with the higher protection afforded by glucose and IGF2 on IL1B-induced apoptosis.

$\beta$-Cell replication was increased in islets exposed to very low IL1B $(1 \mathrm{U} / \mathrm{ml})$ concentration and was severely reduced with higher amounts of IL1B. The mitogenic effect of very low IL1B concentrations is in agreement with the results reported in human islets, a beneficial action that could reflect a physiological role of low cytokine concentrations on islet cells (Maedler et al. 2006). In contrast, higher IL1B concentrations had a clear deleterious effect, and induced a strong inhibition of $\beta$-cell replication. The suppression of $\beta$-cell replication was detected with IL1B concentrations that were insufficient to induce $\beta$-cell apoptosis, indicating a high sensibility of $\beta$-cell replication to IL1B. $\beta$-Cell replication was substantially reduced in rat islets exposed to $10 \mathrm{U} / \mathrm{ml} \mathrm{IL1B}$, and was almost completely suppressed in islets exposed to 30 and $50 \mathrm{U} / \mathrm{ml}$ of IL1B. In contrast, 30 and $50 \mathrm{U} / \mathrm{ml}$ of IL1B was required to consistently increase $\beta$-cell apoptosis.

The strong suppression of $\beta$-cell replication by IL1B was also found in islets overexpressing IGF2. In the absence of IL1B, IGF2 overexpression increased $\beta$-cell replication in islets cultured at low and high glucose concentration in agreement with the well-known mitogenic effects of IGF2 (Hogg et al. 1993, Asfari et al. 1995, Petrik et al. 1999a). In islets exposed to IL1B, IGF2 overexpression had a clear anti-apoptotic action, but resulted in a more modest preservation of $\beta$-cell replication. IGF2 overexpression reduced $\beta$-cell apoptosis in all groups showing IL1B-induced $\beta$-cell apoptosis, but preserved $\beta$-cell replication only in islets exposed to $10 \mathrm{U} / \mathrm{ml}$ IL1B, and had no effects on the suppressed $\beta$-cell replication of islets exposed to 30 or $50 \mathrm{U} / \mathrm{ml} \mathrm{IL1B}$. Overall, the results indicate that $\beta$-cell replication is more sensitive to the deleterious effects of IL1B than $\beta$-cell survival.

The effects of glucose on $\beta$-cell survival are modified by glucose concentration, duration of exposure, and genetic background. In vitro, glucose has been found to promote the survival of rat single $\beta$-cells (Hoorens et al. 1996), but also to induce apoptosis in islets of diabetic-prone animals (Donath et al. 1999), and in human islets (Maedler et al. 2001). In vivo, we have reported increased $\beta$-cell apoptosis in transplanted mice islets exposed to chronic hyperglycemia (Biarnés et al. 2002). The effects of glucose on IL1B-induced apoptosis are not well established, and although high glucose concentrations amplified cell damage in islets exposed to IL1B (Spinas et al. 1988), other studies reported no effects of glucose on IL1B-induced $\beta$-cell apoptosis (Raile et al. 2003, Téllez et al. 2005). In the current study, the use of several IL1B concentrations allowed us to identify the protective action of glucose on IL1B-induced apoptosis. In the absence of IL1B, $\beta$-cell apoptosis was similar in islets incubated at low

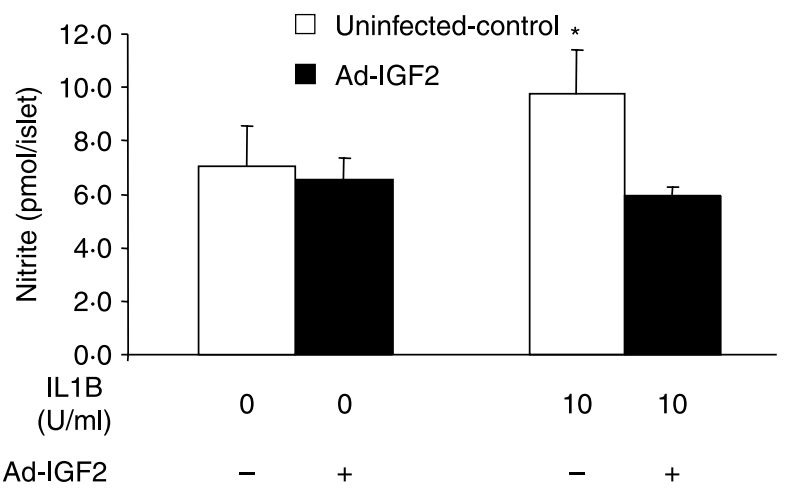

Figure 5 Effects of IL1B and IGF2 overexpression on islet cell production of nitric oxide. Control-uninfected islets and AdIGF2-infected islets were incubated for $48 \mathrm{~h}$ in the presence or absence of $10 \mathrm{U} / \mathrm{ml}$ of IL1B. Nitrite production is expressed as pmol of nitrite/islet every 48 h. Values are means \pm s.E.M. $(n=4) * P<0 \cdot 05$ between control islets exposed to $10 \mathrm{U} / \mathrm{ml}$ IL1B and Ad-IGF2 islets exposed to $10 \mathrm{U} / \mathrm{ml} \mathrm{IL1B}$. 
and high glucose concentration. However, when islets were exposed to $10 \mathrm{U} / \mathrm{ml} \mathrm{IL1B}, \beta$-cell apoptosis was increased in islets cultured at low $(5.5 \mathrm{mmol} / \mathrm{l})$, but not at high $(22.2 \mathrm{mmol} / \mathrm{l})$ glucose, suggesting that glucose had a prosurvival effect. This protective effect of glucose was confirmed in islets overexpressing IGF2 and exposed to $30 \mathrm{U} / \mathrm{ml}$ IL1B that showed increased $\beta$-cell apoptosis only when cultured at low glucose. In contrast, despite the strong and well established proliferative effect of glucose on $\beta$-cells (Swenne 1982, Lingohr et al. 2006) glucose did not modulate the inhibitory effect of IL1B on $\beta$-cell replication, an additional indication of the high sensitivity of $\beta$-cell replication to the deleterious effects of IL1B.

Several of the deleterious effects of IL1B on rodent islets are mediated by NO (Darville \& Eizirik 1998) which is produced by the inducible form of NO synthase (iNOS). We found that in islets exposed to IL1B, NO production was lower in islets overexpressing IGF2 than in control-uninfected islets, suggesting that the protection afforded by IGF2 was mediated in part by the inhibition of iNOS expression. These results are in agreement with the observation that the neonatal peak of islet apoptosis coincides with low IGF2 and with increased iNOS levels, suggesting that IGF2 has an inhibitory effect on NO formation (Petrik et al. 1998). Furthermore, signaling by IGF1 involves the activation of IGF1 receptor, and IGF1 has been shown to decrease IL1B-mediated NO formation by inhibition of iNOS expression and synthesis in rodent islets (Mabley et al. 1997, Castrillo et al. 2000), and to prevent IL1B-mediated NO production in human islets, as well as $\beta$-cell dysfunction and apoptosis (Giannoukakis et al. 2000).

The inhibitory effect of IL1B on $\beta$-cell secretion are well established and have been studied in detail (Eizirik et al. 1988, Scarim et al. 1997). Our experiments have confirmed the profound impairment of $\beta$-cell function induced by IL1B, and we found a limited protection in islets infected with Ad-IGF2. Some studies have shown a role for insulin in adult $\beta$-cell replication and $\beta$-cell mass maintenance (Okada et al. 2007). In our experiments, although IGF2 overexpression partly preserved insulin secretion in islets exposed to high IL1B, $\beta$-cell replication remained fully suppressed, indicating that the secreted insulin was not sufficient to increase $\beta$-cell proliferation.

The high sensitivity of $\beta$-cell replication to IL1B may be relevant for the reduction of $\beta$-cell mass which takes place in diabetes. In normal conditions, $\beta$-cell mass is maintained by a balance between cell regeneration and death, and recent data have shown that $\beta$-cells have a strong potential for regeneration that can compensate severe reductions in $\beta$-cell mass (Dor et al. 2004, Nir et al. 2007), even though $\beta$-cell growth potential could be more limited in human islets (Parnaud et al. 2008). IL1B- induced $\beta$-cell damage has been implicated in the pathogenesis of type 1 diabetes and more recently in type 2 diabetes, essentially based on the suppressive effects of IL1B on $\beta$-cell function and on the induction of $\beta$-cell death. The strong inhibitory effect of IL1B on $\beta$-cell replication that we show suggests that impaired $\beta$-cell replication may be important in the demise of $\beta$-cells in diabetes. The suppression of $\beta$-cell replication could abrogate the replicative response needed to compensate the reduction of $\beta$-cell mass induced by increased $\beta$-cell death. The recent indication that $\beta$-cell replication is not increased in recentonset type 1 diabetic patients could support this hypothesis (Butler et al. 2007). By suppressing $\beta$-cell replication IL1B could prevent the renewal of $\beta$-cells and reduce $\beta$-cell mass even in the absence of increased $\beta$-cell apoptosis.

Adenoviral overexpression is a useful technique to assess the effects achieved by the local and transient administration of proteins with potential therapeutic action. This is of particular interest in islet transplantation, where the expression in the graft of proteins with therapeutic action could obtain the beneficial effect and avoid the unwanted toxicity associated with systemic administration. The beneficial effects of adenoviral overexpression of IGF2 that we have found in vitro provide the bases to tests these effects in in vivo in experimental islet transplantation, a condition where increased levels of IL1B in the graft in the initial days after transplantation are thought to play a deleterious role in the survival of transplanted $\beta$-cells (Montolio et al. 2007). The predominantly peripheral expression of IGF2 in islet cells suggests that the majority of infected cells were endocrine non- $\beta$ cells, most of them $\alpha$-cells. However, since IGF2 is secreted, it was active on more cells than just the islet cells infected by the adenovirus, and exerted a paracrine effect on neighboring cells as indicated by the substantial effects found on $\beta$-cells. The different distribution of endocrine cell types in rodent and human islets, where $\alpha$-cells and $\beta$-cells are scattered throughout the islet, could increase the number of infected $\beta$-cells in human islets. However, the paracrine effect of secreted IGF2 reduces the significance of the specific endocrine cell type that becomes infected by the adenovirus.

In summary, our results indicate that $\beta$-cell replication is highly sensitive to the deleterious effect of IL1B. The strong suppressive effect of IL1B on $\beta$-cell replication may be relevant for the process leading to the loss of $\beta$-cell mass in diabetes. Adenoviral transfer of IGF2 to islets protected against IL1B inhibition of $\beta$-cell replication and IL1Binduced $\beta$-cell apoptosis, and prevented IL1B-induced NO production, suggesting that IGF2 could have a role in strategies to induce the regeneration of $\beta$-cell mass in diabetes or in islet transplantation.

\section{Declaration of interest}

The authors declare that there is no conflict of interest that could be perceived as prejudicing the impartiality of this scientific work.

\section{Funding}

This work was supported by grants from the Juvenile Diabetes Foundation International (1-2002-687), FIS 03/0047 and FIS 06/0891, and the Instituto 
de Salud Carlos III (ISCIII) RCMN (C03/08). CIBER of Diabetes and Associated Metabolic Diseases (CIBERDEM) is a project of ISCIII. Elisabet Estil·les was supported by a grant from Fundació Privada IDIBELL.

\section{Acknowledgements}

We thank Jessica Escoriza for skillful technical assistance.

\section{References}

Asfari M, Wei D, Noel M, Holthuizen PE \& Czernichow P 1995 IGF-II gene expression in a rat insulin-producing $\beta$-cell line (INS-1) is regulated by glucose. Diabetologia 38 927-935.

Biarnés M, Montolio M, Nacher V, Raurell M, Soler J \& Montanya E 2002 $\beta$-Cell death and mass in syngeneically transplanted islets exposed to shortand long-term hyperglycaemia. Diabetes 51 66-72.

Butler AE, Janson J, Bonner-Weir S, Ritzel R, Rizza RA \& Butler PC 2003 B-Cell deficit and increased $\beta$-cell apoptosis in humans with type 2 diabetes. Diabetes 52 102-110.

Butler AE, Galasso R, Meier JJ, Basu R, Rizza RA \& Butler PC 2007 Modestly increased $\beta$-cell apoptosis but no increased $\beta$-cell replication in recent-onset type 1 diabetic patients who died of diabetic ketoacidosis. Diabetologia 50 2323-2331

Castrillo A, Bodelón OG \& Boscá L 2000 Inhibitory effect of IGF-1 on type 2 nitric oxide synthase expression in Ins- 1 cells and protection against activation-dependent apoptosis. Involvement of phosphatidylinositol 3-kinase. Diabetes 49 209-217.

Darville MI \& Eizirik DL 1998 Regulation by cytokines of the inducible nitric oxide synthase promoter in insulin-producing cells. Diabetologia $\mathbf{4 1}$ 1101-1108.

Devendra D, Liu E \& Eisenbarth GS 2004 Type 1 diabetes: recent developments. BMJ 328 750-754.

Donath MY, Gross DJ, Cerasi E \& Kaiser N 1999 Hyperglycemia-induced $\beta$-cell apoptosis in pancreatic islets of Psammomys obesus during development of diabetes. Diabetes 48 738-744.

Dor Y, Brown J, Martinez OI \& Melton DA 2004 Adult pancreatic $\beta$-cells are formed by self-duplication rather than ítem-cell differentiation. Nature $\mathbf{4 2 9}$ 41-46.

Eizirik DL \& Mandrup-Poulsen T 2001 A choice of death. The signal transduction of immune-mediated $\beta$-cell apoptosis. Diabetologia $\mathbf{4 4}$ 2115-2133.

Eizirik DL, Strandell E, Bendtzen K \& Sandler S 1988 Functional characteristics of rat pancreatic islets maintained in culture after exposure to human interleukin 1. Diabetes 37 916-919.

Eizirik DL, Welsh M, Strandell E, Welsh N \& Sandler S 1990 Interleukin-1 $\beta$ depletes insulin messenger ribonucleic acid and increses the heat shock protein hsp70 in mouse pancreatic islets without impairing the glucose metabolism. Endocrinology 127 2290-2297.

Giannoukakis N, Mi Z, Rudert WA, Gambotto A, Trucco M \& Robbins P 2000 Prevention of $\beta$-cell dysfunction and apoptosis activation in human islets by adenoviral gene transfer of the insulin-like growth factor 1. Gene Therapy 7 2015-2022.

Hill DJ, Petrick J, Arany E, McDonald TJ \& Delovitch TL 1999 Insulin-like growth factors prevent cytokine-mediated cell death in isolated islets of Langerhans from pre-diabetic non-obese diabetic mice. Journal of Endocrinology 161 153-165.

Hill DJ, Strutt B, Arany E, Zaina S, Coukell S \& Graham CF 2000 Increased and persistent circulating insulin-like growth factor II in neonatal transgenic mice suppresses developmental apoptosis in the pancreatic islets. Endocrinology 141 1151-1157.

Hogg J, Han VKM, Clemmons DR \& Hill DJ 1993 Interactions of nutrient, insulin-like growth factors (IGFs) and IGF binding proteins in the regulation of DNA synthesis by isolated fetal rat islets of Langerhans. Journal of Endocrinology 138 401-412.
Hoorens A, Van de Casteele M, Kloppel G \& Pipeleers D 1996 Glucose promotes survival of rat pancreatic $\beta$-cells by activating synthesis of proteins which suppress a constitutive apoptotic program. Journal of Clinical Investigation 98 1568-1574.

Hügl SR, White MF \& Rhodes CJ 1998 Insulin-like growth factor I (IGF-I)stimulated pancreatic $\beta$-cell growth is glucose-dependent. Synergistic activation of insulin receptor substrate-mediated signal transduction pathways by glucose and IGF-I in INS-1 cells. Journal of Biological Chemistry 273 17771-17779.

Huotari MA, Palgi J \& Otonkoski T 1998 Growth factor-mediated proliferation and differentiation of insulin-producing INS-1 and RINm5F cells: identification of betacelulin as a novel $\beta$-cell mitogen. Endocrinology 139 1494-1499.

Ilvemarski V, Jattela M, Saksela E \& Voutilainen R 1993 Tumor necrosis factor-alpha and interferon-gamma inhibit insulin-like growth factor-II gene expression in human fetal adrenal cell cultures. Molecular and Cellular Endocrinology 91 59-65.

Larsen CM, Faulenbarch M, Vaag A, Volund A, Ehses JA, Seifert B, Mandrup-Poulsen T \& Donath MY 2007 Interleukin-1-receptor antagonist in type 2 diabetes mellitus. New England Journal of Medicine 356 $1517-1526$.

Lin T, Wang DL, Nagpal ML \& Cahang W 1994 Recombinant murine tumor necrosis factor alpha inhibits cholesterol side-chain cleavage cytochrome P450 and insulin-like growth factor-I gene expression in rat Leydig cells. Molecular and Cellular Endocrinology 101 111-119.

Lingohr MK, Briaud I, Dickson LM, McCuaig JF, Alarcon C, Wicksteed BL \& Rhodes CJ 2006 Specific regulation of IRS-2 expression by glucose in rat primary pancreateic islet $\beta$-cells. Journal of Biological Chemistry 281 15884-15892.

Mabley JG, Belin V, John N \& Green IC 1997 Insulin-like growth factor I reverses interleukin-1 $\beta$ inhibition of insulin secretion, induction of nitric oxide synthase and cytokine-mediated apoptosis in rat islets of Langerhans. FEBS Letters 417 235-238.

Maedler K, Spinas GA, Lehman R, Sergeev P, Weber M, Fontana A, Kaiser N \& Donath MY 2001 Glucose induces $\beta$-cell apoptosis via upregulation of the Fas receptor in human islets. Diabetes 50 1683-1690.

Maedler K, Schumann DM, Sauter N, Ellingsgaard H, Bosco D, Baertschiger R, Iwakura Y, Oberholzer J, Wollheim CB, Gauthier BR et al. 2006 Low concentration of interleukin- $1 \beta$ induces FLICE-inhibitory protein-mediated $\beta$-cell proliferation in human pancreatic islets. Diabetes $\mathbf{5 5}$ 2713-2722.

Mandrup-Poulsen T 1996 The role of interleukin-1 in the pathogenesis of insulin-dependent diabetes mellitus. Diabetologia 39 1005-1029.

Martin DM, Carlson R \& Feldman EL 1993 Interferon-gamma inhibits DNA synthesis and insulin-like growth factor-II expression in human neuroblastoma cells. Journal of Neuroscience Research 34 489-501.

Mathis D, Vence L \& Benoist C $2001 \beta$-Cell death during progression to diabetes. Nature 414 792-798.

Meier JJ, Butler AE, Saisho Y, Monchamp T, Galasso R, Bhushan A, Rizza RA \& Butler PC $2008 \beta$-Cell replication is the primary mechanism subserving the postnatal expansion of $\beta$-cell mass in humans. Diabetes $\mathbf{5 7}$ 1584-1594.

Montanya E, Nacher V, Biarnés M \& Soler J 2000 Linear correlation between $\beta$-cell mass and body weight throughout the lifespan in Lewis rats. Diabetes 49 1341-1346.

Montolio M, Biarnés M, Téllez N, Escoriza J, Soler J \& Montanya E 2007 IL-1 $\beta$ and iNOS expression in early syngeneic islet transplantation. Journal of Endocrinology 192 171-179.

Nácher V, Raurell M, Merino JF, Aranda O, Soler J \& Montana E 1996 ß-Cell growth and mass are preserved in long-term syngeneic islet transplantation in streptozocin-induced diabetic Lewis rats. Diabetes 45 1541-1546.

Nir T, Melton DA \& Dor Y 2007 Recovery from diabetes in mice by $\beta$-cell regeneration. Journal of Clinical Investigation 117 2553-2561.

Okada T, Liew CW, Hu J, Hinault C, Michael MD, Krtzfeldt J, Yin C, Holzenberger M, Stoffel M \& Kulkarni RN 2007 Insulin receptors in betacells are critical for islet compensatory growth response to insulin resistance. PNAS 104 8977-8982. 
Parnaud G, Bisco D, Berney T, Pattou F, Kerry-Conte J, Donath MY, Bruun C, Mandrup-Poulsen T, Billestrup N \& Halban PA 2008 Proliferation of sorted human and rat $\beta$-cells. Diabetologia 51 91-100.

Persidsky MD \& Baillie GS 1977 Fluorometric test of cell membrane integrity. Cryobiology 14 322-331.

Petrik J, Arany E, McDonald TJ \& Hill DJ 1998 Apoptosis in the pancreatic islet cells of the neonatal rat is associated with a reduced expression of insulin-like growth factor II that may act as a survival factor. Endocrinology 139 2994-3004.

Petrik J, Pell JM, Arany E, McDonald TJ, Dean WL, Reik W \& Hill DJ 1999a Overexpression of insulin-like growth factor-II in transgenic mice is associated with pancreatic islet cell hyperplasia. Endocrinology 140 2353-2363.

Petrik J, Reusens B, Arany E, Remacle C, Coelho C, Hoet JJ \& Hill DJ 19996 A low protein diet alters the balance of islet cell replication and apoptosis in the fetal and neonatal rat and is associated with a reduced pancreatic expression of insulin-like growth factor-II. Endocrinology 140 4861-4873.

Raile K, Berthold A, Banning U, Horn F, Pfeiffer G \& Kiess W 2003 IGFs, basic FGF, and glucose modulate proliferation and apoptosis induced by IFN $\gamma$ but not by IL-1 $\beta$ in rat INS-1E $\beta$-cells. Hormone and Metabolic Research 35 407-414.

Robitaille R, Dusseault J, Henley N, Rosenberg L \& Hallé JP 2003 Insulinlike growth factor II allows prolonged blood glucose normalization with reduced islet cell mass transplantation. Endocrinology 144 3037-3045.

Saldeen J 2000 Cytokines induce both necrosis and apoptosis via a common Bcl-2-inhibitable pathway in rat insulin-producing cells. Endocrinology 141 2003-2010.

Scaglia L, Cahill CJ, Finegood DT \& Bonner-Weir S 1997 Apotosis participates in the remodeling of the endocrine pancreas in the neonatal rat. Endocrinology 138 1736-1741.

Scarim AL, Heitmeier MR \& Corbett JA 1997 Irreversible inhibition of metabolic function and islet destruction after a 36-hour exposure to interleukin-1ß. Endocrinology 138 5301-5307.
Sjöholm A 1991 Inhibition of fetal rat pancreatic $\beta$-cell replication by interleukin- $1 \beta$ in vitro is not mediated through pertussis toxin-sensitive G-proteins, a decrease in cyclic AMP, or protease activation. FEBS Letters $289249-252$

Southern C, Schulster D \& Green IC 1990 Inhibition of insulin secretion from rat islets of Langerhans by interleukin-6. An effect distinct from that of interleukin-1. Biochemical Journal 272 243-245.

Spinas GA, Palmer JP, Mandrup-Poulsen T, Andersen H, Nielsen JH \& Nerup J 1988 The bimodal effect of interleukin 1 on rat pancreatic $\beta$-cells -stimulation followed by inhibition- depends upon dose, duration of exposure, and ambient glucose concentration. Acta Endocrinologica 119 307-311.

Swenne I 1982 The role of glucose in the in vitro regulation of cell cycle kinetics and proliferation of fetal pancreatic B-cells. Diabetes 31 754-760.

Téllez N, Montolio M, Biarnés M, Castaño E, Soler J \& Montanya E 2005 Adenoviral overexpression of interleukin-1 receptor antagonist protein increases $\beta$-cell replication in rat pancreatic islets. Gene Therapy $\mathbf{1 2}$ $120-128$.

Téllez N, Montolio M, Estillles E, Escoriza J, Soler J \& Montanya E 2007 Adenoviral overproduction of interleukin-1 receptor antagonist increases $\beta$-cell replication and mass in syngeneically transplanted islets, and improves metabolic outcome. Diabetologia 50 602-611.

Vasavada RC, Gonzalez-Pertusa JA, Fujinaka Y, Fiaschi-Taesch N, Cozar-Castellano I \& Garcia Ocaña A 2006 Growth factors and $\beta$-cell replication. International Journal of Biochemistry \& Cell Biology 38 931-950.

Received in final form 27 May 2009

Accepted 10 July 2009

Made available online as an Accepted Preprint

10 July 2009 